\title{
Effect of cytokinesis inhibitors, DMSO and the timing of oocyte activation on mouse cloning using cumulus cell nuclei
}

\author{
T. Wakayama* and R. Yanagimachi \\ The Institute for Biogenesis Research, Department of Anatomy and Reproductive Biology, \\ University of Hawaii School of Medicine, Honolulu, HI 96822, USA
}

\begin{abstract}
Cloning methods are now well described and in almost routine use. However, the frequencies of production of live offspring from activated oocytes remain at $<3 \%$ and little is known about the factors that affect these frequencies. The effects of cytokinesis inhibitors, dimethylsulphoxide (DMSO) and the cell cycle of recipient cytoplasm on the cloning of mice were examined. Reconstructed oocytes, which were activated immediately after nucleus injection and cultured without cytochalasin B, developed into blastocysts at a frequency of $30-54 \%$ and into live cloned offspring at a frequency of $2-3 \%$. Activated zygotes did not support development to full term after nuclear transfer. Reconstructed oocytes were activated 1-3 $\mathrm{h}$ after nuclear transfer and were exposed separately to three inhibitors of cytokinesis (cytochalasin B, cytochalasin D or nocodazole) to examine the toxicity of these
\end{abstract}

inhibitors on cloning. All of the oocytes exposed to nocodazole-containing media formed many small pseudopronuclei, whereas with cytochalasin-containing media most of the activated oocytes formed only two pseudo-pronuclei. Despite such differences, $42-61 \%$ of reconstructed embryos developed to the morula-blastocyst stage and 1-3\% developed to full term in all groups. Addition of $1 \%(\mathrm{v} / \mathrm{v})$ DMSO to the activation medium significantly improved the frequency of development to the blastocyst stage and full term; however, this improvement did not lead to a higher success rate in the generation of live cloned offspring. These results show that activated mouse oocytes/ zygotes are not effective cytoplasmic recipients with the methods described and that the lack of success of cloning is not due to inhibition of cytokinesis.

\section{Introduction}

Cloning mammals by nuclear transfer began more than twenty years ago, yet the basic biology underlying this process remains unclear. A Piezo-electric nuclear transfer method has been used to generate cloned mice from cumulus cells (Wakayama et al., 1998a, 2000a, 2001; Wakayama and Yanagimachi, 2001) and tail-tip cells (Wakayama and Yanagimachi, 1999) of adult animals as well as embryonic stem cells (Wakayama et al., 1999; Rideout et al., 2000). Ogura et al. (2000a) also reported cloning live mice using Sertoli cells by the same Piezoelectric injection method. Recently, other methods, such as cell fusion (Ogura et al., 2000b; Ono et al., 2001) or injection without a Piezo-electric device (Zhou et al., 2000) were used successfully to produce live cloned mice. However, as in other mammals, the overall efficiency of mouse cloning (the percentage of live offspring obtained from all activated oocytes) in all reports is $<3 \%$.

Why is the success rate of cloning so low? Is it because only a few per cent of any cell population are 'cloningcompetent' or simply because of technical problems? It is likely that many technical factors such as cell cycle, oocyte

*Present address: Advanced Cell Technology, One Innovation Drive, Worcester, MA 01605, USA

Email: teru@advancedcell.com activation and chemical agents affect development of cloned embryos.

In our mouse cloning protocol, donor nuclei are exposed to the cytoplasm of the unfertilized oocyte for a few hours, which causes nuclear envelope breakdown and premature chromosome condensation (Czolowska et al., 1984; Collas and Robl, 1991) due to the action of the maturation/ metaphase promoting factor (Masui and Markert, 1971) within the cytoplasm of the oocyte. Methods that induce premature chromosome condensation in reconstructed oocytes result in increased developmental potential, indicating that these processes may promote reprogramming of gene expression in the donor nucleus (Collas and Robl, 1991; Cibelli et al., 1998; Wakayama et al., 1998a, 2000b; Wells et al., 1999; Onishi et al., 2000). In contrast, cytoplasts derived from activated oocytes or pronuclear zygotes lack active maturation/metaphase promoting factor and so do not induce nuclear envelope breakdown or premature chromosome condensation in transferred nuclei (Czolowska et al., 1984; Campbell et al., 1994, 1996a). In some cases, enucleated oocytes were activated before nuclear transfer, culminating in the birth of cloned pigs, cows and sheep (Prather et al., 1989; Stice et al., 1994; Campbell et al., 1996b). Therefore, a clear understanding of the role of premature chromosome condensation and maturation/ metaphase promoting factor in the development of reconstructed embryos requires further study. 
After exposure to maturation/metaphase promoting factor, reconstructed mouse oocytes must be activated for development to progress. Kishikawa et al. (1999) demonstrated that four different methods for oocyte activation (strontium, ethanol, electro-stimulation and sperm injection) yielded about the same rates $(1-2 \%)$ of cloning success. It is interesting to note that for cloning, strontium (which we have been using routinely) is as active as sperm-born factors in oocyte activation; therefore, the choice of activation method is not critical. However, in no instance have we obtained evidence to support the possibility that enucleated zygotes can be used successfully as recipients for somatic cell nuclei. In studies in which we sought such evidence no zygotes developed to blastocysts, the transferred nuclei became extremely fragmented and development was arrested at the two-cell stage (Wakayama et al., 2000b). This finding was in contrast to the very early and never independently confirmed report by IIImensee and Hoppe (1981) that zygotes could be used in this fashion (McGrath and Solter, 1984a).

In our protocol, reconstructed mouse oocytes activated by the above reagents are treated with cytochalasin to prevent the loss of somatic cell chromosomes into the pseudo-polar body (Wakayama et al., 1998a). Several methods have been proposed to prevent cell division or polar body extrusion (Opas, 1977; Modlinski and McLaren, 1980; Siracusa et al., 1980; Surani et al., 1980; Borsuk, 1982). The most commonly used reagents are cytochalasin B or D (Snow, 1973; Siracusa et al., 1980; Bos-Mikich et al., 1997) and latrunculin B (Schatten et al., 1986), which disrupt actin filaments. Other commonly used agents are colcemid, colchicine (Kleinfeld and Sisken, 1966; Borisy and Taylor, 1967), vinblastin (Siracusa et al., 1980) and nocodazole (Johnson et al., 1988), all of which interfere with microtubule assembly. These treatments prevent cytokinesis and, therefore, extrusion of the polar body. It has been reported that nocodazole is the least harmful to mouse development before and after implantation (Kato and Tsunoda, 1992; Otaegui et al., 1994).

In the present study, the effects of timing of oocyte/ zygote activation and duration of in vitro culture of cloned embryos on the success rate of cloning mice by nuclear injection methods were investigated. The effect of dimethylsulphoxide (DMSO) on embryo development was also investigated, as this reagent is included routinely in the oocyte activation medium. Finally, whether the agents used to prevent polar body extrusion affect cloning efficiency was examined.

\section{Materials and Methods}

\section{Animals}

B6D2F1 (C57BL/6 $\times$ DBA/2) female mice, aged 8-10 weeks, were used as oocyte and cumulus cell donors. Foster mothers were CD-1 females. The females were mated with vasectomized males of the same strain. All animals used in this study were maintained in accordance with the guidelines of the Laboratory Animal Service at the University of Hawaii and those prepared by the Committee on Care and Use of Laboratory Animals of the Institute of Laboratory Resources National Research Council (DHEF publication no. [NIH] 8023, revised in 1985). The protocol for animal handling and treatment procedures was reviewed and approved by the Animal Care and Use Committee at the University of Hawaii.

\section{Reagents}

All inorganic and organic compounds were purchased from Sigma Chemical Co (St Louis, MO) unless otherwise stated.

\section{Media}

Oocytes, zygotes and embryos were all cultured in a bicarbonate-buffered (CZB) medium (Chatot et al., 1990) at $37.5^{\circ} \mathrm{C}$ under $5 \% \mathrm{CO}_{2}$ in air. Oocyte manipulations were carried out in Hepes-buffered CZB (Hepes-CZB) at room temperature $\left(25-29^{\circ} \mathrm{C}\right)$ in air. The $\mathrm{pH}$ of these media was approximately 7.5. $\mathrm{Ca}^{2+}$-free CZB containing both $10 \mathrm{mmol}$ $\mathrm{SrCl}_{2} \mathrm{I}^{-1}$ and $5 \mu \mathrm{g}$ cytochalasin $\mathrm{B} \mathrm{m} \mathrm{m}^{-1}$ was used to activate reconstructed oocytes (Bos-Mikich et al., 1997). Stock solutions of $\mathrm{Sr}^{2+}\left(100 \mathrm{mmol} \mathrm{\textrm {I } ^ { - 1 }}\right.$ in distilled water $)$ and cytochalasin B (500-10000 $\mathrm{g} \mathrm{ml}^{-1}$ in DMSO) were stored at room temperature and $-20^{\circ} \mathrm{C}$, respectively. Immediately before use, $\mathrm{Sr}^{2+}$ stock solution was diluted with $\mathrm{Ca}^{2+}$-free $\mathrm{CZB}$ to a final concentration of $10 \mathrm{mmol} \mathrm{Sr}^{2+} \mathrm{I}^{-1}$ (this is oocyte activation medium). Cytochalasin B, D and nocodazole were dissolved in DMSO and diluted in activation medium to final concentrations of 5, 1 and $3 \mu \mathrm{g} \mathrm{m}^{-1}$, respectively, while the DMSO concentration varied between $0.05 \%(\mathrm{v} / \mathrm{v})$ and $1.00 \%(\mathrm{v} / \mathrm{v})$.

\section{Isolation of cumulus cells, oocytes and zygotes}

Mature B6D2F1 female mice were induced to superovulate by consecutive injections of equine chorionic gonadotrophin (eCG; $5 \mathrm{iu}$ ) and hCG (5 iu) $48 \mathrm{~h}$ apart. Thirteen to $15 \mathrm{~h}$ after hCG injection, cumulus-oocyte complexes were collected from oviducts. Cumulus cells were dispersed by a 10 min treatment with $0.1 \%(\mathrm{w} / \mathrm{v})$ bovine testicular hyaluronidase (300 USP units $\mathrm{mg}^{-1}$; ICN Pharmaceuticals, Costa Mesa, CA) in Hepes-CZB. An aliquot (about $2 \mu \mathrm{l}$ ) of the cumulus cell suspension was transferred to $20 \mu \mathrm{l}$ Hepes-CZB, containing $12 \%(\mathrm{w} / \mathrm{v})$ polyvinylpyrrolidone $\left(M_{\mathrm{r}} 360000\right)$ and kept at room temperature for up to $3 \mathrm{~h}$ before injection. B6D2F1 females were housed with normal CD-1 males soon after hCG injection and were killed $20 \mathrm{~h}$ later to collect zygotes. Zygotes collected from oviducts were freed from cumulus cells by hyaluronidase treatment, and kept in CZB at $37.5^{\circ} \mathrm{C}$ under $5 \% \mathrm{CO}_{2}$ in air for $<1 \mathrm{~h}$ before further treatment.

\section{Enucleation of oocytes and zygotes}

Oocytes. A group of oocytes (usually 20-30) was transferred to a droplet (about $10 \mu \mathrm{l}$ ) of Hepes-CZB containing 
$5 \mu \mathrm{g}$ cytochalasin $\mathrm{B} \mathrm{ml}^{-1}$, which had been placed previously under mineral oil in the operation chamber on the microscope stage. After an oocyte was held by an oocyte-holding pipette, its zona pellucida was 'drilled' by applying several Piezo pulses to the tip of an enucleation pipette (Wakayama et al., 1998a). The metaphase II chromosome-spindle complex, distinguished as a translucent spot in the ooplasm, was drawn into the pipette with a small amount of accompanying ooplasm and pulled gently away from the oocyte until a stretched cytoplasmic bridge was pinched off. After oocytes in one group were enucleated (which took about $10 \mathrm{~min}$ ), they were transferred into cytochalasin B-free CZB and kept there for up to $2 \mathrm{~h}$ at $37.5^{\circ} \mathrm{C}$ (Wakayama et al., 1998a). The efficiency of enucleation was $100 \%$ as assessed by fixing and staining (Yanagida et al., 1991).

Zygote. Zygotes (pronuclear eggs) were placed in cytochalasin B-containing Hepes CZB. After the zona pellucida was 'drilled' by Piezo-pulses, both female and male pronuclei were drawn into the pipette, then pulled gently away from the zygote until a stretched cytoplasmic bridge was pinched off.

Parthenogenetically activated oocytes. Oocytes were activated by incubation for $1 \mathrm{~h}$ in $\mathrm{Ca}^{2+}$-free CZB containing $10 \mathrm{mmol} \mathrm{Sr}{ }^{2+} \mathrm{I}^{-1}$ medium. After cumulus cell nuclei were injected into activated oocytes, the oocytes were transferred into $\mathrm{CZB}$ medium and kept at $37^{\circ} \mathrm{C}, 5 \% \mathrm{CO}_{2}$ in air to allow for membrane recovery. After 20-30 min, telophase II chromosomes were removed as described for metaphase II chromosomes.

Injection of cumulus cell nuclei into enucleated oocytes, zygotes and activated oocytes

A cumulus cell was drawn in and out of the injection pipette until the plasma membrane was broken. In some cases, a few Piezo pulses were applied to break the membranes. After a cumulus cell nucleus was drawn deep into the pipette, another cell nucleus was drawn into the same pipette. Within a few minutes several nuclei were lined up within a single pipette. These nuclei were injected individually into enucleated oocytes as described for the spermatid nucleus injection (Kimura and Yanagimachi, 1995a,b) except that all handling was performed at room temperature $\left(25-29^{\circ} \mathrm{C}\right)$ instead of $17-18^{\circ} \mathrm{C}$. Kimura and Yanagimachi (1995a) reported that oocytes operated on at $17-18^{\circ} \mathrm{C}$ survived better than at high temperature, but we later found that this is not necessarily the case. All nuclei were injected into oocytes or zygotes within 10 min after denudation.

\section{Oocyte activation conditions and inhibition of polar body formation}

Activation media condition (i). Reconstructed oocytes were activated by incubation at $37^{\circ} \mathrm{C}$ for $6-7 \mathrm{~h}$ in $\mathrm{Ca}^{2+}$ free CZB containing both $10 \mathrm{mmol} \mathrm{Sr}^{2+} \mathrm{I}^{-1}$ and $5 \mu \mathrm{g}$ cytochalasin $\mathrm{B} \mathrm{ml} \mathrm{ml}^{-1}$. The final concentration of DMSO was $0.05 \%-1.00 \%(\mathrm{v} / \mathrm{v})$.

When reconstructed oocytes were activated immediately after nuclear transfer, the nucleus in each oocyte enlarged without dissolution of the nuclear membrane (Czolowska et al., 1984) and, therefore, cytochalasin B was not added. However, in some experiments, DMSO and cytochalasin B were added for control experiments.

Activation media condition (ii). Reconstructed oocytes were activated by incubation at $37^{\circ} \mathrm{C}$ for $6-7 \mathrm{~h}$ in $\mathrm{Ca}^{2+}$-free

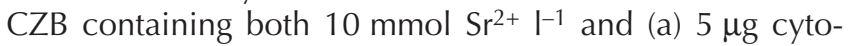
chalasin $\mathrm{B} \mathrm{ml}^{-1}$ and $1 \%(\mathrm{v} / \mathrm{v})$ DMSO, (b) $1 \mu \mathrm{g}$ cytochalasin $\mathrm{D} \mathrm{ml}^{-1}$ and $0.1 \%(\mathrm{v} / \mathrm{v}) \mathrm{DMSO}$, (c) $1 \mu \mathrm{g}$ cytochalasin $\mathrm{D} \mathrm{ml}^{-1}$ and $1 \%(\mathrm{v} / \mathrm{v})$ DMSO or $(\mathrm{d}) 3 \mu \mathrm{g}$ nocodazole $\mathrm{I}^{-1}$ with $1 \%(\mathrm{v} / \mathrm{v})$ DMSO.

Some activated oocytes were fixed and stained to examine pseudo-pronuclei formation (Yanagida et al., 1991). Activated oocytes at the pseudo-pronuclear stage were washed and cultured in $\mathrm{Sr}^{2+}$-free $\mathrm{CZB}$ until they reached the two-cell or morula-blastocyst stage.

\section{Oocyte activation protocols}

Five different protocols were used to activate oocytes (see Fig. 1). In the first protocol (Fig. 1a: pre-activation experiment) enucleated oocytes were activated $1 \mathrm{~h}$ before cumulus cell nuclei were injected. In the second protocol (Fig. 1b: immediate activation experiment) enucleated oocytes were activated within 5 min of injection of cumulus cell nuclei. In the third protocol (Fig. 1c: post-activation experiment) enucleated oocytes were activated $1-3 \mathrm{~h}$ after injection of cumulus cell nuclei. In the fourth protocol (Fig. $1 \mathrm{~d}$ : zygote experiment) male and female pronuclei were removed simultaneously and before injection of cumulus cell nuclei. In the fifth protocol (Fig. 1e: non-enucleated pre-activation experiment) intact oocytes were activated. Cumulus cell nuclei were injected $1 \mathrm{~h}$ later and within 30 min, telophase II chromosomes were removed. Oocytes in this group always contained nuclei of the oocyte or the cumulus cell or both. In other experiments, the oocytes were temporarily free of a nucleus.

\section{Embryo transfer and examination of fetuses and placentae}

Two-cell embryos ( $24 \mathrm{~h}$ after onset of activation) were transferred into oviducts of foster mothers (CD-1, albino) that had been mated with vasectomized CD-1 males 1 day previously. Morulae or blastocysts (78 $\mathrm{h}$ after activation) were transferred into the uteri of foster mothers (CD-1, albino) that had been mated with vasectomized CD-1 males 3 days previously. All recipient females were killed at day 19.5 post coitus and their uteri were examined for the presence of fetuses and implantation sites. Live young were raised by lactating CD-1 foster mothers. Offspring and placentae were weighed individually. 
(a) Pre-activation

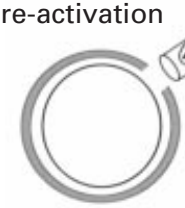

Removal of

metaphase II chromosomes

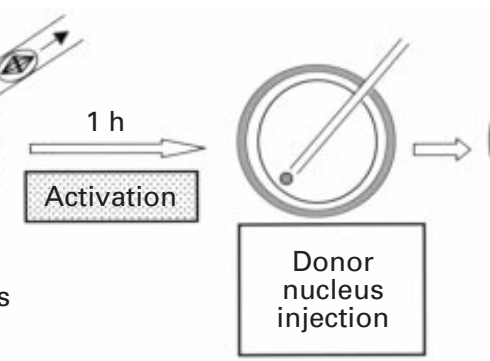

(see Fig. 2a)

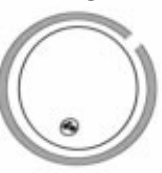

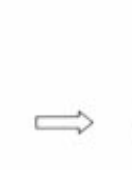

(see Fig. 2b)

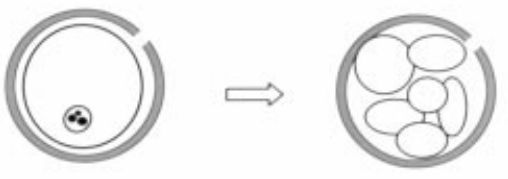

Formation of small pseudopronucleus

Mostly fragmented

(b) Immediate activation

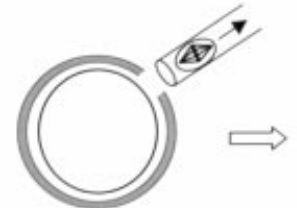

Removal of metaphase II chromosomes
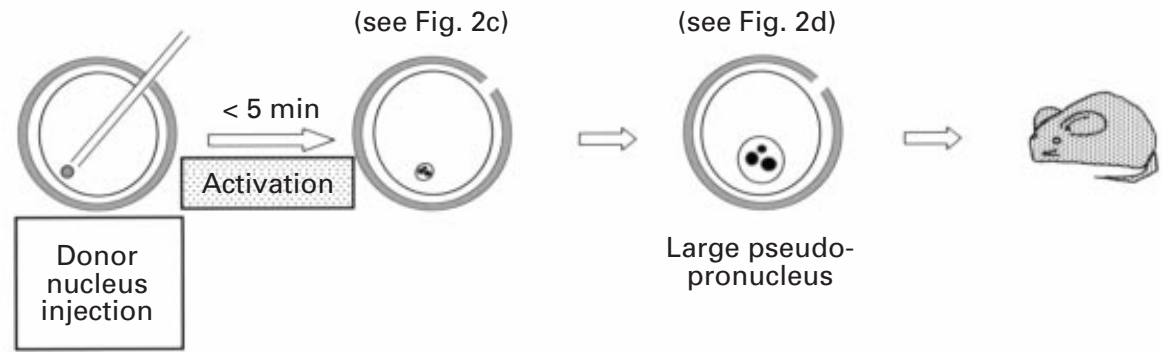

(c) Post-activation

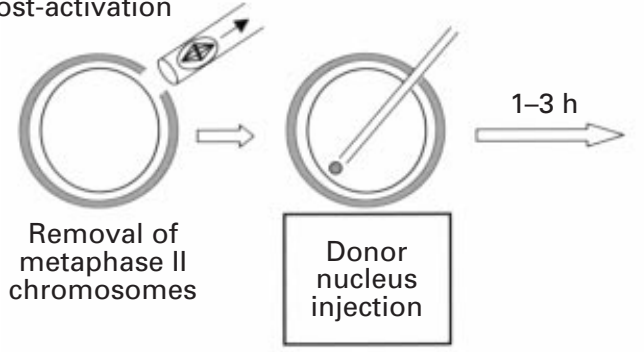

(see Fig. 2e)

(see Fig. 2f)
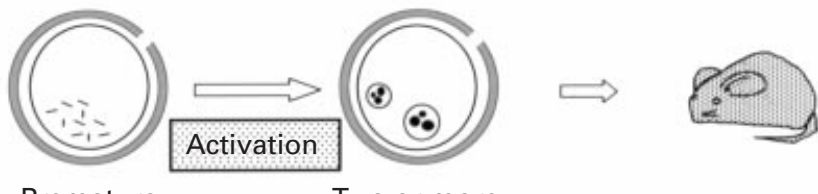

chromosome condensation

Two or more

pseudo-

pronuclei

(d) Zygote
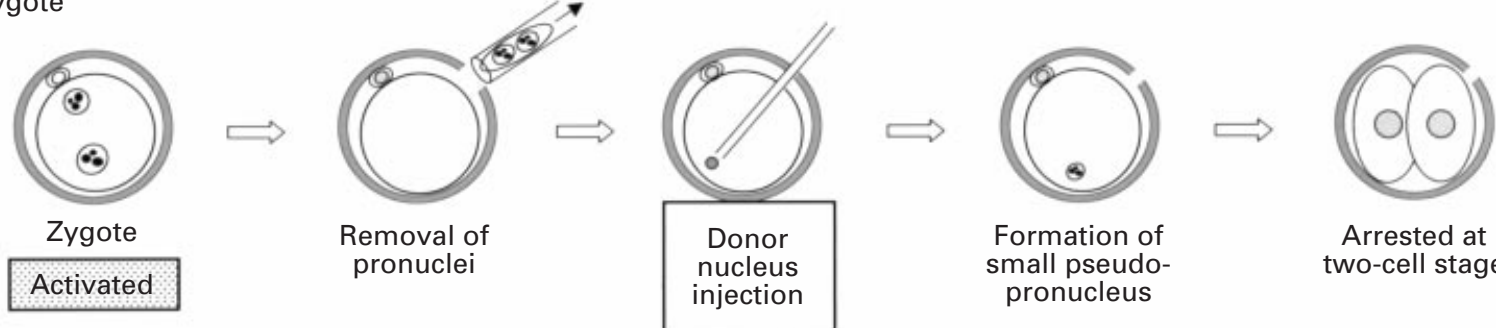

Arrested at two-cell stage

(e) Non-enuleated pre-activation
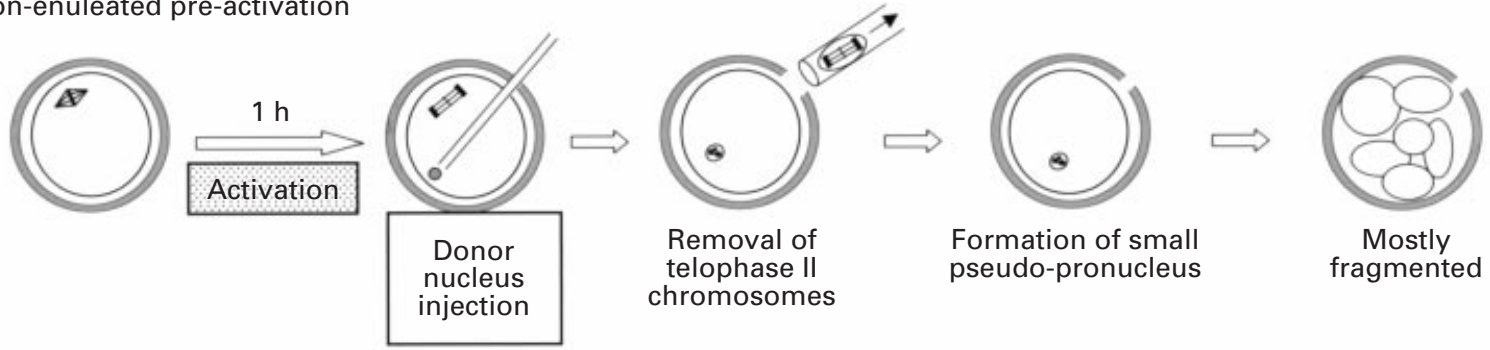

Fig. 1. Five oocyte activation protocols. (a) Protocol A: oocytes were enucleated and then activated, before injection of donor nuclei. (b) Protocol B: enucleated oocytes were activated immediately after nuclear transfer. (c) Protocol C: enucleated oocytes were activated 1-3 h after nuclear transfer. (d) Protocol D: enucleated zygotes were injected with donor nuclei. (e) Protocol E: intact oocytes were first activated and donor nuclei were injected before removal of the telophase II chromosomes of the oocyte. 


\section{Results}

\section{Timing of activation}

Oocytes activated $1 \mathrm{~h}$ before nuclear transfer (Fig. 1a). These oocytes contained a small nucleus at the onset of activation (Fig. 2a) which changed into a small pseudopronucleus over the next $6 \mathrm{~h}$ (Fig. 2b). Most of these embryos underwent irregular cleavages and only a small percentage developed into blastocysts (Table 1). After subsequent transfer to four foster mothers (2-3 blastocysts per female), none of these blastocysts developed to term. In our control experiment (Tamashiro et al., 2000), in which fertilized embryos (2-3 embryos per female) were transferred into each recipient, most females delivered one or two offspring. Therefore, the failure of cloned embryo development is not due to transfer of too few embryos.

Activation of reconstructed oocytes immediately after nuclear transfer. This resulted in a markedly different nuclear morphology and developmental potential (Fig. 1b). The reconstructed oocytes contained one small nucleus at $1 \mathrm{~h}$ after activation (Fig. 2c) that became a large pseudopronucleus during the next $6 \mathrm{~h}$ (Fig. 2d). Of these, 30-54\% developed into blastocysts (Table 1).

Reconstructed oocytes incubated for 1-3 $h$ before activation (Fig. 1c and Table 1). This activation protocol was used for the production of our first cloned mouse 'Cumulina' and her clones (Wakayama et al., 1998a, 2000a). During this period of incubation the transferred nuclei were transformed into randomly arranged chromosomes (Fig. 2e). When the oocytes were activated in the presence of cytochalasin $\mathrm{B}$, the chromosomes were transformed into two or more pseudo-pronuclei (Fig. 2f). Of these activated oocytes, 38-69\% reached the blastocyst stage (Table 1).

\section{Zygotes as recipients of donor nuclei}

When enucleated zygotes were used as recipients of donor nuclei (Fig. 1d), none developed beyond the two-cell stage (Table 2). Similarly, embryos reconstructed from activated oocytes (Fig. 1e) never developed beyond the four-cell stage and upon closer examination it was observed that they contained fragmented nuclei (Table 2).

\section{DMSO and cytokinesis inhibitors}

The effects of DMSO on embryo development were examined at the same time (Table 1). The presence of $0.1-1.0 \%(\mathrm{v} / \mathrm{v})$ DMSO in the oocyte activation medium further promoted the preimplantation development of embryos to the blastocyst stage. Medium containing $<0.1 \%$ $(v / v)$ DMSO supports development to the blastocyst stage but at a reduced rate (Fig. $3 ; P<0.05$ ).

The results of in vivo experiments in which mature oocytes were enucleated and activated immediately after nuclear transfer (same method as Fig. 1b) are shown (Table
3). The oocytes were activated in the absence or presence of $1 \%(\mathrm{v} / \mathrm{v}) \mathrm{DMSO}$, or $1 \%(\mathrm{v} / \mathrm{v})$ DMSO plus $5 \mu \mathrm{g}$ cytochalasin $\mathrm{B} \mathrm{ml} \mathrm{m}^{-1}$ (activation media condition (i)). The highest frequency of preimplantation development was observed when oocytes were activated by $\mathrm{Sr}^{2+}$ in the presence of $1 \%$ $(\mathrm{v} / \mathrm{v})$ DMSO. The presence of cytochalasin B or absence of DMSO in the activation medium resulted in a significant decrease in the frequency of development to the blastocyst stage. Furthermore, when reconstructed oocytes were activated in cytochalasin B-containing medium, none developed to term. However, six live offspring were obtained from other experimental groups (a frequency of $2-3 \%$, mean body weight $1.62 \mathrm{~g}$ and mean placental mass $0.31 \mathrm{~g}$ ).

The results of another series of experiments in which pseudo-polar body extrusion was prevented by the separate use of three different cytokinesis inhibitors (activation media condition (ii)) are shown (Table 4). When reconstructed oocytes were treated with $\mathrm{Sr}^{2+}$ in the presence of cytochalasin B or cytochalasin D, reconstructed zygotes had two or three pseudo-pronuclei. In contrast, when reconstructed oocytes were activated with nocodazole, reconstructed zygotes had many small pseudo-pronuclei (Fig. 4). However, 1-3\% of reconstructed oocytes developed to full term, irrespective of treatment. When reconstructed embryos were transferred to surrogate mothers at the two-cell or morula-blastocyst stage (Table 4), a mean 2.7 and $5.3 \%$ of transferred embryos developed to full term, respectively. However, when the success rates of full term development were calculated based on all reconstructed oocytes, those success rates were 2.0 and $2.5 \%$, respectively.

\section{Evidence that all pups were derived from somatic cell nuclei by nuclear transfer}

All cloned mice were female and had black eyes. All surrogate mothers were CD-1 (albino with red eyes) and were mated with CD-1 vasectomized males, resulting in pseudopregnancy without fetuses. Even if natural mating had occurred accidentally, any resultant pups would be albino with red eyes. Furthermore, in these studies, cells from male mice were never used as nucleus donors; therefore it was expected that all 22 cloned mice would be female. This is theoretically a very unlikely outcome (occurring at a frequency of $1 / 2^{22}$ ) if the offspring had arisen via normal reproduction. Finally, all pups were born with large placentae, which is only seen in somatic cell cloned mice (Wakayama et al., 1998a; Kishikawa et al., 1999; Wakayama and Yanagimachi, 1999; Ogura et al., 2000a,b; Tamashiro et al., 2000; Wakayama et al., 2000a; Ono et al., 2001; Wakayama and Yanagimachi, 2001). For the above reasons, it was concluded that all pups were derived absolutely from somatic cell nuclei by nuclear transfer.

\section{Discussion}

Wakayama et al. (2000b) showed that embryos reconstructed using oocyte cytoplasts had normal 

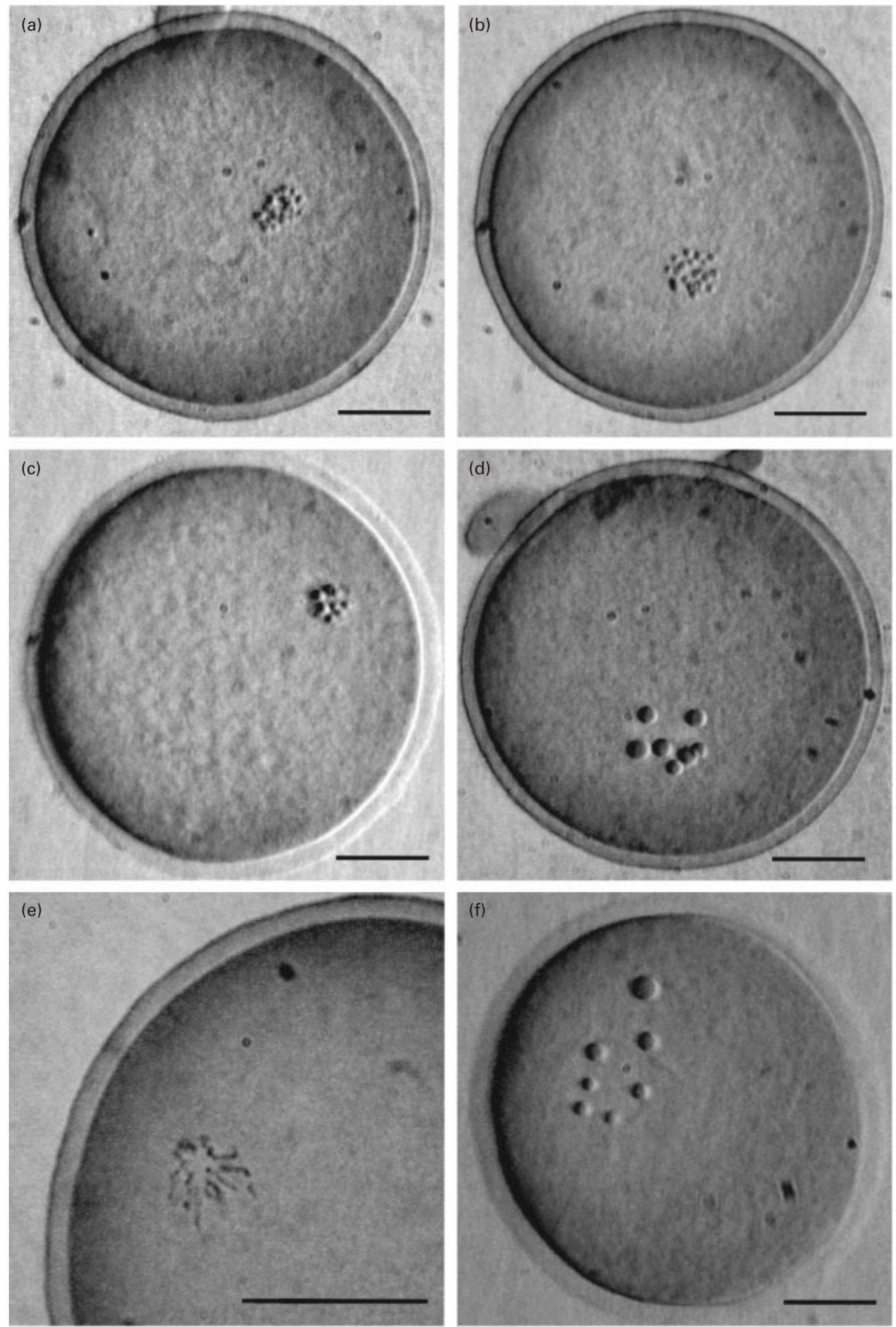

Fig. 2. Cumulus cell nuclei after transfer into oocytes (a) 1 and (b) $6 \mathrm{~h}$ after oocyte activation by protocol A, (c) 1 and (d) $6 \mathrm{~h}$ after oocyte activation by protocol B, and (e ) 1-3 h after injection into an unactivated enucleated oocyte. Note that the nucleus is transformed into loosely arranged chromosomes by protocol C. (f) Reconstructed oocytes activated in the presence of cytochalasin B (chromosomes transform into two or more pseudo-pronuclei by protocol C). Scale bars represent $20 \mu \mathrm{m}$. 
Table 1. Effects of the timing of oocyte activation and DMSO on development of cumulus-injected oocytes in vitro

\begin{tabular}{|c|c|c|c|c|c|c|c|}
\hline \multirow{2}{*}{$\begin{array}{l}\text { Oocyte } \\
\text { activation }\end{array}$} & \multirow{2}{*}{$\begin{array}{l}\text { Concentration } \\
\text { of DMSO in } \\
\text { medium }(\% ; \mathrm{v} / \mathrm{v})\end{array}$} & \multirow{2}{*}{$\begin{array}{l}\text { Number of } \\
\text { enucleated } \\
\text { oocytes }\end{array}$} & \multirow{2}{*}{$\begin{array}{c}\text { Number } \\
\text { of surviving } \\
\text { oocytes after } \\
\text { nucleus } \\
\text { injection }\end{array}$} & \multirow{2}{*}{$\begin{array}{l}\text { Number } \\
(\%) \text { of } \\
\text { activated } \\
\text { oocytes }\end{array}$} & \multicolumn{3}{|c|}{$\begin{array}{l}\text { Number }(\% \pm \text { SD) of embryos examined } \\
96 \mathrm{~h} \text { after oocyte activation }\end{array}$} \\
\hline & & & & & One-cell & Two- to eight-cell & Blastocyst** \\
\hline \multirow{2}{*}{$\begin{array}{l}1 \text { h before nucleus } \\
\text { injection (Fig. 1a) }\end{array}$} & 0 & 103 & 99 & - & 85 & 12 & $4(4.0 \pm 3.2)$ \\
\hline & 1.00 & 104 & 98 & - & 85 & 10 & $7(7.2 \pm 7.0)$ \\
\hline \multirow{6}{*}{$\begin{array}{l}\text { Immediately after } \\
\text { nucleus injection } \\
\text { (Fig. 1b) }\end{array}$} & 0 & 103 & 103 & $94(91.3)$ & 27 & 37 & $38(37.3 \pm 34.3)^{\mathrm{a}}$ \\
\hline & 0.01 & 102 & 100 & $88(88.0)$ & 22 & 44 & $28(29.8 \pm 22.5)^{\mathrm{a}}$ \\
\hline & 0.10 & 102 & 99 & $92(92.9)$ & 24 & 31 & $42(43.3 \pm 31.2)$ \\
\hline & 1.00 & 117 & 114 & $102(89.5)$ & 17 & 34 & $61(54.0 \pm 26.3)^{b}$ \\
\hline & 2.00 & 106 & 92 & $80(87.0)$ & 22 & 23 & $47(51.1 \pm 14.4)$ \\
\hline & $1.00^{*}$ & 100 & 72 & $66(91.7)$ & 22 & 22 & $28(38.9 \pm 19.0)$ \\
\hline \multirow{5}{*}{$\begin{array}{l}\text { 1-3 h after } \\
\text { nucleus injection } \\
\text { (Fig. 1c) }\end{array}$} & $0.05^{*}$ & 164 & 154 & $138(90.2)$ & 20 & 76 & $58(37.7 \pm 19.4)^{\mathrm{c}}$ \\
\hline & $0.10^{*}$ & 126 & 126 & $124(98.4)$ & 8 & 53 & $65(51.6 \pm 18.5)^{\mathrm{de}}$ \\
\hline & $0.50 *$ & 117 & 113 & $105(93.8)$ & 10 & 31 & $72(63.7 \pm 16.7)^{\mathrm{d}}$ \\
\hline & $1.00^{*}$ & 151 & 144 & $133(95.0)$ & 19 & 26 & $99(68.8 \pm 15.3)^{\mathrm{df}}$ \\
\hline & $2.00^{*}$ & 142 & 134 & $134(100)$ & 5 & 56 & $73(54.5 \pm 9.7)^{\mathrm{de}}$ \\
\hline
\end{tabular}

This experiment was replicated three times.

*5 $\mu$ g cytochalasin $\mathrm{B} \mathrm{ml}^{-1}$ was included in the oocyte activation medium to prevent polar body extrusion.

**Data were analysed using the chi-squared test $(P<0.05)$ : a versus $b, c$ versus $d$ and e versus $f$.

Table 2. In vitro development of reconstructed zygote and telophase Il oocytes receiving cumulus cell nuclei

\begin{tabular}{|c|c|c|c|c|c|c|c|c|}
\hline \multirow{2}{*}{$\begin{array}{l}\text { Nucleus } \\
\text { recipients }\end{array}$} & \multirow{2}{*}{$\begin{array}{l}\text { Number of } \\
\text { prepared eggs }\end{array}$} & \multirow{2}{*}{$\begin{array}{c}\text { Number of } \\
\text { enucleated } \\
\text { zygotes }\end{array}$} & \multirow{2}{*}{$\begin{array}{l}\text { Number of } \\
\text { surviving eggs } \\
\text { after nucleus } \\
\text { injection }\end{array}$} & \multirow{2}{*}{$\begin{array}{c}\text { Number of } \\
\text { enucleated } \\
\text { telophase II } \\
\text { oocytes after } \\
\text { nucleus } \\
\text { injection }\end{array}$} & \multicolumn{4}{|c|}{$\begin{array}{c}\text { Number (\%) of embryos examined } \\
96 \text { h after nucleus injection }\end{array}$} \\
\hline & & & & & One-cell & Two-cell & Four-cell & $\geq$ Eight-cell \\
\hline Zygote (Fig. 1d) & 109 & 98 & 91 & - & $41(45.1)$ & $50(54.9)$ & 0 & 0 \\
\hline $\begin{array}{l}\text { Telophase II oocytes } \\
\text { (Fig. 1e) }\end{array}$ & 105 & - & 101 & 97 & $45(46.4)$ & $46(47.4)$ & $6(6.2)$ & 0 \\
\hline
\end{tabular}

This experiment was replicated three times.

karyotype, whether oocytes were activated before, immediately after or $1-3 \mathrm{~h}$ after nuclear transfer. In contrast, when enucleated zygotes supplied the recipient cytoplast, the transferred nuclei became extremely fragmented (Wakayama et al., 2000b). In the present study, embryos reconstructed using zygotes also failed to develop. These zygotes were activated $6 \mathrm{~h}$ before nuclear transfer and were probably in early S-phase of the first embryonic cell division cycle. This cell cycle stage may be incompatible with that of cells in an adult animal and such asynchronization could result in developmental failure of reconstructed embryos. A similar phenomenon was observed in experiments in which the second polar body was exchanged with the female pronucleus in zygotes in early developmental stages (Wakayama et al., 1997); then, live offspring were obtained. However, when zygotes at late stages were used, the zygote exchanged did become fragmented, again probably due to asynchronization of the cell cycle of the zygote and the polar body. Taken together, these results indicate that enucleated zygotes may be unsuitable for use in cloning of adult animals.

In all successful nuclear transfer experiments reported to date, nuclei of recipient oocytes were removed before fusion or injection of donor nuclei. In such experiments several hours elapsed between nuclear removal and nuclear transfer, during which time the recipient oocyte lacked nuclear contents. Unactivated oocytes are arrested in metaphase II of the cell cycle; activation relieves this arrest and numerous changes follow (for example, a decrease in maturation/metaphase promoting factor activity). If activated enucleated oocytes are used as recipient cytoplasm, this tumultuous period takes place in the absence of a nucleus. If a nucleus is essential during this change, recipient eggs might be irreparably damaged before nuclear transfer. 


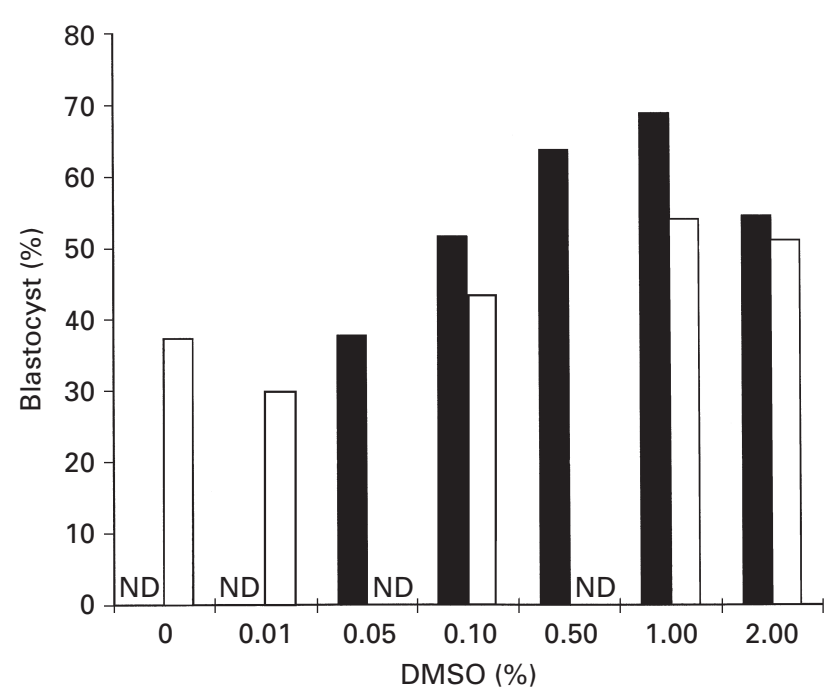

Fig. 3. Effect of dimethylsulphoxide (DMSO) on pre-implantation development of oocytes injected with cumulus cell nuclei by protocol B ( $\square$; see Fig. 1b) and protocol C ( $\square$; see Fig. 1c) assessed at $96 \mathrm{~h}$ after activation.

Cumulus cell nuclei were injected into activated oocytes and then telophase II chromosomes were removed to determine whether this lack of a nucleus prevented normal embryonic development in activated oocytes. Thus, these reconstructed oocytes never lacked a nucleus; despite this, none developed beyond the four-cell stage. This finding shows that the poor developmental capacity observed when using activated oocytes is not due to the absence of chromosomes per se.

When donor nuclei are exposed to oocyte cytoplasm for several hours, an inhibitor of cytokinesis must be added to the activation medium to prevent chromosome loss through extrusion of the pseudo-second polar body (Kono et al., 1993; Cheong et al., 1994; Wakayama et al., 1998a). If the 'immediate activation' method is used, an inhibitor of cytokinesis is not required, as reconstructed oocytes activated immediately after nuclear transfer do not induce premature chromosome condensation or do not extrude pseudo-polar body.
With our protocol, cytochalasin B was detrimental to embryonic development when reconstructed oocytes were activated immediately after nuclear transfer. In our previous study (Wakayama et al., 1998a), oocytes were exposed to cytochalasin B regardless of the time of activation. Under those conditions, no fetuses were obtained from oocytes activated immediately after nuclear transfer. Similar results were obtained in the present study. When reconstructed oocytes are activated in the presence of cytochalasin B, decreased blastocyst development is observed and none progressed to live-born young after transfer. However, live cloned mice were obtained in the absence of cytochalasin $B$, using the immediate activation method. It is important to note that other studies have reported that exposure to cytochalasin B resulted in an improved success rate of embryonic development in cloning of rabbits (Collas and Robl, 1990) and sheep (Smith and Wilmut, 1989). The reason for this discrepancy is unclear.

In the immediate activation experimental condition, oocytes are exposed to activation medium within 5 min after nuclear transfer. Strontium induces activation in B6D2F1 oocytes within $25 \mathrm{~min}$ (T. Wakayama and R. Yanagimachi, unpublished). Therefore, the introduced nucleus is exposed to high maturation/metaphase promoting factor activity for between $5 \mathrm{~min}$ and $30 \mathrm{~min}$. If exposure of the transferred nucleus to ooplasmic maturation/ metaphase promoting factor activity is indeed critical for genome reprogramming, these results indicate that the necessary changes take place rapidly. When donor nuclei are exposed to oocyte cytoplasm for $>1 \mathrm{~h}$, the reprogramming of donor nuclei may be enhanced and stabilized further. Therefore, those reconstructed oocytes might develop even when activated with cytochalasin-containing medium.

Cytochalasin B may cause damage to embryo development. Therefore, if pseudo-second polar body extrusion could be prevented without cytochalasin B, the success rate of cloning might be increased. For this reason, we compared the effects of several different cytokinesis inhibitors on cloning. Cytochalasins B and D are microfilamentdisrupting reagents and are often used to induce polyploidy

Table 3. Full term development of reconstructed oocytes activated immediately after nuclear injection with or without DMSO and cytochalasin B

\begin{tabular}{|c|c|c|c|c|c|c|}
\hline $\begin{array}{l}\text { DMSO and cytochalasin B in } \\
\text { oocyte-activating medium }\end{array}$ & $\begin{array}{c}\text { Number of } \\
\text { enucleated } \\
\text { oocytes }\end{array}$ & $\begin{array}{l}\text { Number of } \\
\text { surviving } \\
\text { oocytes } \\
\text { after nucleus } \\
\text { injection }\end{array}$ & $\begin{array}{c}\text { Number }(\%) \\
\text { of activated } \\
\text { oocytes }\end{array}$ & $\begin{array}{c}\text { Number } \\
\text { (\% } \pm \text { SD) of } \\
\text { oocytes that } \\
\text { developed to } \\
\text { blastocyst } \\
\text { stage* }\end{array}$ & $\begin{array}{l}\text { Number of } \\
\text { embryos } \\
\text { transferred } \\
\text { (recipients) }\end{array}$ & $\begin{array}{c}\text { Number }(\%) \\
\text { of live } \\
\text { offspring }\end{array}$ \\
\hline $1 \%$ DMSO and cytochalasin B & 172 & 135 & $102(75.6)$ & $59(43.7 \pm 14.8)^{\mathrm{a}}$ & $59(5)$ & 0 \\
\hline $1 \%$ DMSO & 257 & 235 & $193(82.1)$ & $153(65.1 \pm 17.3)^{b}$ & $149(9)$ & $3(1.3)$ \\
\hline None & 252 & 220 & $168(76.4)$ & $101(46.0 \pm 24.2)^{\mathrm{a}}$ & $97(7)$ & $3(1.4)$ \\
\hline
\end{tabular}

This experiment was performed using protocol B and was replicated five times.

DMSO: dimethylsulphoxide ( $v / v)$.

*Data were analysed using the chi-squared test $(P<0.05)$ : a versus $b$. 


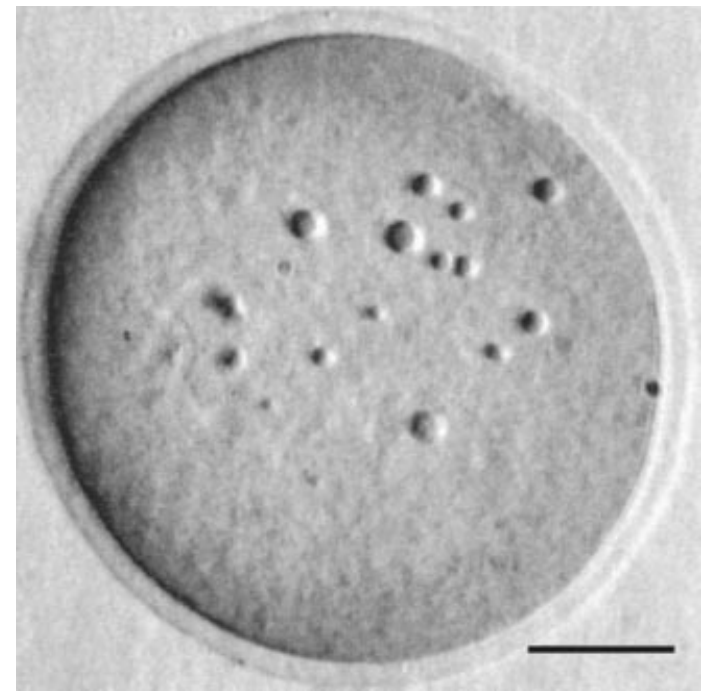

Fig. 4. Pseudo-pronuclei at $6 \mathrm{~h}$ after activation of oocytes that had been treated with activation medium containing $3 \mu \mathrm{g}$ nocodazole $\mathrm{ml}^{-1}$. Scale bar represents $20 \mu \mathrm{m}$.

in preimplantation embryos (Snow, 1973; Siracusa et al., 1980; Bos-Mikich et al., 1997). Although these drugs do not affect development to the blastocyst stage in vitro (Siracusa et al., 1980), their effect on full term development is unclear, as aneuploid embryos and parthenogenetic embryos can not develop to full term (Epstein, 1986; McGrath and Solter, 1984b; Surani et al., 1984). Nocodazole is an inhibitor of tubulin polymerization and causes breaks in the metaphase spindle and, thus, is often used for cell cycle synchronization experiments (Johnson et al., 1988). It has also been reported that this drug does not affect development to full term (Kato and Tsunoda, 1992; Otaegui et al., 1994; Samake and Smith, 1996).

In the present study, all reagents succeeded in preventing pseudo-polar body extrusion. When cytochalasin B or D was used, reconstructed zygotes had two or three pseudopronuclei. This finding was expected because cytochalasin cannot disrupt the metaphase plate and so chromosomes were pulled to the centrosomes by actin filaments. However, when nocodazole was used, reconstructed zygotes had many small pseudo-pronuclei because the metaphase plate was broken, causing chromosomes to separate inside the oocytes. Before the present study, we had hypothesized that the low cloning success rate might be due to the use of cytochalasin, but apparently this is not the case, as the substitution of nocodazole did not increase the success rate beyond $2-3 \%$.

Thus, neither the method of oocyte activation (Kishikawa et al., 1999) nor the type of cytokinesis inhibitor (present study) can account for the low success rate of cloning.

The effect of transfer of two-cell embryos into the oviduct and transfer of morulae or blastocysts into uteri were also compared. It has been generally believed that the duration of in vitro culture should be minimized to promote developmental progression of manipulated embryos.
Therefore, one-cell or two-cell embryos were usually transferred into day 1 oviducts. However, recently, the in vitro culture system of mouse embryos was improved allowing most in vitro fertilization/intracytoplasmic sperm injection (IVF/ICSI) embryos to develop to full term. In the present study, the percentage of live offspring per transfer was considerably higher when embryos were transferred into uteri of surrogate mothers at the morula-blastocyst stage $(5.3 \%)$ than when embryos were transferred into oviducts at the two-cell stage (2.7\%). In our laboratory, when IVF/ICSI embryos were transferred at the two-cell stage into oviducts or at the morula-blastocyst stage into uteri, the success rate of full term is almost the same (60-61\% of two-cell transfers: Wakayama et al., 1995; Tanemura et al., 1997; Wakayama et al., 1998b; 50-57\% of morula-blastocyst transfers: Wakayama and Yanagimachi, $1998 a, b, c)$. Therefore, this difference in success rate was not due to a technical problem.

When reconstructed oocytes were cultured for 1 day, $87 \%$ of cloned embryos developed to the two-cell stage, but when cultured for 4 days, 53\% developed to the morulablastocyst stage. It is possible that some of those transferred at the two-cell stage were not developmentally competent and might never develop to the morula-blastocyst stage. However, at this point, it is not possible to predict which two-cell embryos have a good chance to develop to term, and we continue to transfer all two-cell embryos into surrogate mothers. Therefore, the success rate of full term development from transfer of two-cell embryos is lower $(2.7 \%)$ than from blastocyst transfer $(5.3 \%)$, but the overall percentage from reconstructed oocytes was the same in both cases (2.3 versus $2.8 \%$, respectively). These results are similar to those observed with IVF and implantation of human embryos (Gardner et al., 1998).

In our experiments DMSO was used to dissolve cytochalasin B and so was present in the medium during oocyte activation. A DMSO concentration of $1 \%(\mathrm{v} / \mathrm{v})$ was used in initial experiments. The effect of DMSO on embryonic development (Wood et al., 1993) was assessed by decreasing the DMSO concentration to one hundredth of the original concentration. To our surprise, there was a correlation between the concentration of DMSO (in the presence of $\mathrm{Sr}^{2+}$ ) in the activation medium and the frequency of development to the blastocyst stage and to full term development. Although Morley and Whitfield (1993) had shown that DMSO causes the release of $\mathrm{Ca}^{2+}$ from intracellular stores, we had been unable previously to induce oocyte activation with $1-6 \mathrm{~h}$ exposure to $0.05-2.00 \%(\mathrm{v} / \mathrm{v})$ DMSO in the absence of $\mathrm{Sr}^{2+}$ (Imahie et al., 1995; T. Wakayama and R. Yanagimachi, unpublished). Therefore, in our experiments, oocyte activation must have been induced by $\mathrm{Sr}^{2+}$ rather than by DMSO. Interestingly, DMSO is known to cause differentiation of embryonic teratocarcinoma cells into cardiac and skeletal muscle (McBurney et al., 1982; Rudnicki et al., 1990; Vidricaire et al., 1994). In those cases, DMSO affected differentiation from embryonic teratocarcinoma cells to somatic cells, but 


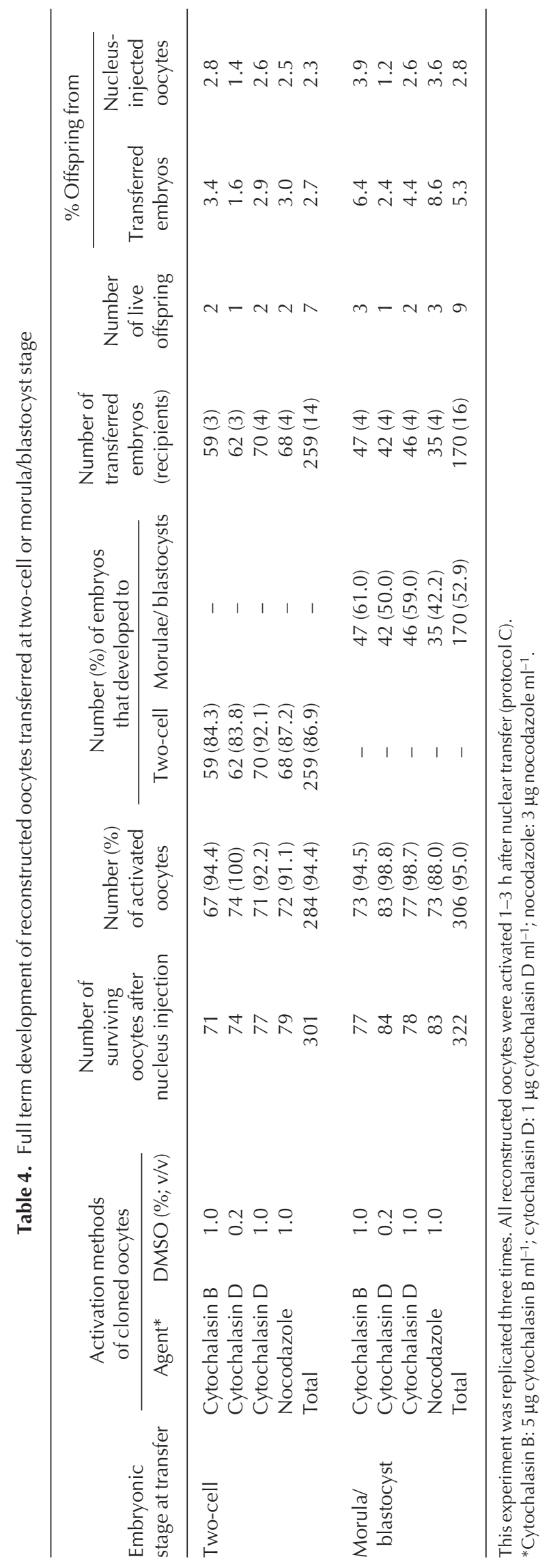


for nuclear transfer, DMSO might affect reprogramming of somatic cell nuclei after or during oocyte activation.

The authors would like to thank N. Krieger for reading the original manuscript. This study was supported by grants from the Harold K. Castle Foundation, Victoria and Bradley Geist Foundation, and the Kosasa Family Foundation.

\section{References}

Borisy GG and Taylor EW (1967) The mechanism of action of colchicine. Binding of colchincine- $3 \mathrm{H}$ to cellular protein Journal of Cell Biology 34 525-533

Borsuk E (1982) Preimplantation development of gynogenetic diploid mouse embryos Journal of Embryology and Experimental Morphology $69215-222$

Bos-Mikich A, Whittingham DG and Kones KT (1997) Meiotic and mitotic $\mathrm{Ca}^{2+}$ oscillations affect cell composition in resulting blastocysts Developmental Biology 182 172-179

Campbell KH, Loi P, Cappai P and Wilmut I (1994) Improved development to blastocyst of ovine nuclear transfer embryos reconstructed during the presumptive S-phase of enucleated activated oocytes Biology of Reproduction 50 1385-1393

Campbell KHS, Loi P, Otaegui PJ and Wilmut I (1996a) Cell cycle coordination in embryo cloning by nuclear transfer Reviews of Reproduction 1 40-45

Campbell KHS, McWhir J, Ritchie WA and Wilmut I (1996b) Sheep cloned by nuclear transfer from a cultured cell line Nature 380 64-66

Chatot CL, Lewis JL, Torres I and Ziomek CA (1990) Development of 1-cell embryos from different strains of mice in CZB medium Biology of Reproduction 42 432-440

Cheong HT, Takahashi $\mathbf{Y}$ and Kanagawa H (1994) Relationship between nuclear remodeling and subsequent development of mouse embryonic nuclei transferred to enucleated oocytes Molecular Reproduction and Development 37 138-145

Cibelli JB, Stice SL, Golueke PJ, Kane JJ, Jerry J, Blackwell C, Ponce de Leon FA and Robl JM (1998) Cloned transgenic calves produced from nonquiescent fetal fibroblasts Science $\mathbf{2 8 0} 1256-1258$

Collas P and Robl JM (1990) Factors affecting the efficiency of nuclear transplantation in the rabbit embryo Biology of Reproduction 43 877-884

Collas P and Robl JM (1991) Relationship between nuclear remodeling and development in nuclear transplant rabbit embryos Biology of Reproduction 45 455-465

Czolowska R, Modlinski JA and Tarkowski AK (1984) Behaviour of thymocyte nuclei in non-activated and activated mouse oocytes Journal of Cell Science 69 19-34

Epstein CJ (1986) The Consequences of Chromosome Imbalance. Cambridge University Press, Cambridge

Gardner DK, Schoolcraft WB, Wagley L, Schlenker T, Stevens J and Hesla J (1998) A prospective randomized trial of blastocyst culture and transfer in in-vitro fertilization Human Reproduction 13 3434-3440

Illmensee K and Hoppe PC (1981) Nuclear transplantation in Mus musculus: developmental potential of nuclei from preimplantation embryos Cell 23 9-18

Imahie H, Sato E and Toyoda Y (1995) Parthenogenetic activation induced by progesterone in cultured mouse oocytes Journal of Reproduction and Development 41 7-14

Johnson MH, Pickering SJ, Dhiman A, Radcliffe GS and Maro B (1988) Cytocortical organization during natural and prolonged mitosis of mouse 8-cell blastomeres Development 102 143-158

Kato Y and Tsunoda Y (1992) Synchronous division of mouse two-cell embryos with nocodazole in vitro. Journal of Reproduction and Fertility 95 39-43

Kimura Y and Yanagimachi R (1995a) Intracytoplasmic sperm injection in the mouse Biology of Reproduction 52 709-720

Kimura Y and Yanagimachi R (1995b) Mouse oocytes injected with testicular spermatozoa or round spermatids can develop into normal offspring Development 121 2397-2405
Kishikawa H, Wakayama T and Yanagimachi R (1999) Comparison of oocyte-activating agents for mouse cloning Cloning 1 153-159

Kleinfeld RG and Sisken JE (1966) Morphological and kinetic aspects of mitotic arrest by and recovery from colcemid Journal of Cell Biology 31 369-379

Kono T, Ogawa M and Nakahara T (1993) Thymocyte transfer to enucleated oocytes in the mouse Journal of Reproduction and Development 39 301-307

McBurney MW, Jones-Villeneuve EM, Edwards MK and Anderson PJ (1982) Control of muscle and neuronal differentiation in a cultured embryonal carcinoma cell line Nature 299 165-167

McGrath J and Solter D (1984a) Inability of mouse blastomere nuclei transferred to enucleated zygotes to support development in vitro. Science 226 1317-1319

McGrath J and Solter D (1984b) Completion of mouse embryogenesis requires both the maternal and paternal genomes Cell 37 179-183

Masui Y and Markert CL (1971) Cytoplasmic control of nuclear behavior during meiotic maturation of frog oocytes Journal of Experimental Zoology 177 129-145

Modlinski J and McLaren A (1980) A method for visualizing the chromosomes of the second polar body of the mouse egg Journal of Embryology and Experimental Morphology 60 93-97

Morley P and Whitfield JF (1993) The differentiation inducer, dimethyl sulfoxide, transiently increases the intracellular calcium ion concentration in various cell types Journal of Cell Physiology 156 219-225

Ogura A, Inoue K, Ogonuki N et al. (2000a) Production of male cloned mice from fresh, cultured, and cryopreserved immature sertoli cells Biology of Reproduction 62 1579-1584

Ogura A, Inoue K, Takano K, Wakayama T and Yanagimachi R (2000b) Birth of mice after nuclear transfer by electrofusion using tail tip cells Molecular Reproduction and Development 57 55-59

Onishi A, Iwamoto M, Akita T, Mikawa S, Takeda K, Awata T, Hanada H and Perry AC (2000) Pig cloning by microinjection of fetal fibroblast nuclei Science 289 1188-1190

Ono Y, Shimozawa N, Ito M and Kono T (2001) Cloned mice from fetal fibroblast cells arrested at metaphase by a serial nuclear transfer Biology of Reproduction 64 44-50

Opas J (1977) Effects of extremely low osmolarity on fertilized mouse eggs Journal of Embryology and Experimental Morphology 37 65-77

Otaegui PJ, O'Neill GT, Campbell KH and Wilmut I (1994) Transfer of nuclei from 8-cell stage mouse embryos following use of nocodazole to control the cell cycle Molecular Reproduction and Development 39 $147-152$

Prather RS, Sims MM and First NL (1989) Nuclear transplantation in early pig embryos Biology of Reproduction 41 414-418

Rideout WM, III, Wakayama T, Wutz A, Eggan K, Jackson-Grusby L, Dausman J, Yanagimachi R and Jaenisch R (2000) Generation of mice from wild-type and targeted ES cells by nuclear cloning Nature Genetics 24 109-110.

Rudnicki MA, Jackowski G, Saggin L and McBurney MW (1990) Actin and myosin expression during development of cardiac muscle from cultured embryonal carcinoma cells Developmental Biology 138 348-358

Samake S and Smith LC (1996) Effects of cell-cycle-arrest agents on cleavage and development of mouse embryos Journal of Experimental Zoology 274 111-120

Schatten G, Schatten H, Spector I, Cline C, Paweletz N, Simerly C and Petzelt C (1986) Latrunculin inhibits the microfilament-mediated processes during fertilization, cleavage and early development in sea urchins and mice Experimental Cell Research 166 191-208

Siracusa G, Whittingham DG and DeFelici M (1980) The effect of microtubule- and microfilament-disrupting drugs on preimplantation mouse embryos Journal of Embryology and Experimental Morphology $6071-82$

Smith LC and Wilmut I (1989) Influence of nuclear and cytoplasmic activity on the development in vivo of sheep embryos after nuclear transplantation Biology of Reproduction 40 1027-1035

Snow MHL (1973) Tetraploid mouse embryos produced by cytochalasin B during cleavage Nature 244 513-515

Stice SL, Keefer CL and Matthews L (1994) Bovine nuclear transfer 
embryos: oocyte activation prior to blastomere fusion Molecular Reproduction and Development 38 61-68

Surani MA, Barton SC and Burling A (1980) Differentiation of 2-cell and 8cell mouse embryos arrested by cytoskeletal inhibitors Experimental Cell Research 125 275-286

Surani MAH, Barton SC and Norris ML (1984) Development of reconstituted mouse eggs suggests imprinting of the genome during gametogenesis Nature 308 548-550

Tamashiro KL, Wakayama T, Blanchard RJ, Blanchard DC and Yanagimachi R (2000) Postnatal growth and behavioral development of mice cloned from adult cumulus cells Biology of Reproduction 63 328-334

Tanemura K, Wakayama T, Kuramoto K, Hayashi Y and Ogura A (1997) Birth of normal young by microinsemination with frozen-thawed round spermatids collected from aged azoospermic mice Laboratory Animal Science 47 203-204

Vidricaire G, Jardine K and McBurney MW (1994) Expression of the Brachyury gene during mesoderm development in differentiating embryonal carcinoma cell cultures Development 120 115-122

Wakayama T and Yanagimachi R (1998a) Fertilizability and developmental ability of mouse oocytes with reduced amount of cytoplasm Zygote 6 $341-346$

Wakayama T and Yanagimachi R (1998b) The first polar body can be used in the production of normal offspring Biology of Reproduction $\mathbf{5 9}$ 100-104

Wakayama T and Yanagimachi R (1998c) Development of normal mice from oocytes injected with freeze-dried spermatozoa Nature Biotechnology 16 639-641

Wakayama T and Yanagimachi R (1999) Cloning of male mice from adult tail-tip cells Nature Genetics 22 127-128

Wakayama T and Yanagimachi R (2001) Mouse cloning with nucleus donor cells of different age and type Molecular Reproduction and Development 58 376-383

Wakayama T, Tanemura K, Suto J, Imamura K, Fukuta K, Mori H, Kuramoto K, Kurohmaru M and Hayashi Y (1995) Production of term offspring by in vitro fertilization using old mouse spermatozoa Journal of Veterinary Medical Science 57 545-547

Wakayama T, Hayashi Y and Ogura A (1997) Participation of the female pronucleus derived from the second polar body in full embryonic development of mice Journal of Reproduction and Fertility 110 263-266

Wakayama T, Perry ACF, Zuccotti M, Johnson KR and Yanagimachi R (1998a) Full-term development of mice from enucleated oocytes injected with cumulus cell nuclei Nature 394 369-374

Wakayama T, Whittingham DG and Yanagimachi R (1998b) Production of normal offspring from mouse oocytes injected with spermatozoa cryopreserved with or without cryoprotection Journal of Reproduction and Fertility 112 11-17

Wakayama T, Rodriguez I, Perry ACF, Yanagimachi R and Mombearts P (1999) Mice cloned from embryonic stem cell Proceedings National Academy of Sciences USA 96 14984-14989

Wakayama T, Shinkai Y, Tamashiro KL et al. (2000a) Cloning of mice to six generations Nature 407 318-319

Wakayama T, Tateno H, Mombaerts P and Yanagimachi R (2000b) Nuclear transfer into mouse zygotes Nature Genetics 24 108-109

Wakayama T, Tabar V, Rodriguez I, Perry ACF, Studer L and Mombaerts P (2001) Differentiation of embryonic stem cell lines generated from adult somatic cells by nuclear transfer Science 292 740-743

Wells DN, Misica PM and Tervit HR (1999) Production of cloned calves following nuclear transfer with cultured adult mural granulosa cells Biology of Reproduction 60 996-1005

Wood MJ, Barros C, Candy CJ, Carroll J, Melendez J and Whittingham DG (1993) High rates of survival and fertilization of mouse and hamster oocytes after vitrification in dimethylsulphoxide Biology of Reproduction 49 489-495

Yanagida K, Yanagimachi R, Perreault SD and Kleinfeld RG (1991) Thermostability of sperm nuclei assessed by microinjection into hamster oocytes Biology of Reproduction 44 440-447

Zhou Q, Boulanger L and Renard JP (2000) A simplified method for the reconstruction of fully competent mouse zygotes from adult somatic donor nuclei Cloning 2 35-44

Received 16 November 2000

First decision 12 February 2001.

Accepted 23 March 2001. 